Pedagogik Jurnal Pendidikan, Maret 2014, Volume 9 Nomor 1, (52-63)

\title{
PENGARUH PENGAJARAN CRITICAL THINKING TERHADAP MAHASISWA DALAM ARGUMENTATIVE ESSAY
}

\author{
Oleh : A'am Rifaldi Khunaifi *
}

\begin{abstract}
Abstrak
Penelitian ini ditujukan untuk mengetahui apakah pengajaran berpikir kritis dapat mempengaruhi kemampuan mahasiswa dalam Essay argumentatif . Secara khusus, itu diarahkan untuk menyelidiki apakah mengajar karya pemikiran kritis dan dapat memberikan efek positif terhadap Essay argumentatif Mahasiswa Untuk Semester Keenam Pada STAIN Palangka Raya Tahun Akademik 2013/ 2014.

Populasi ini studyis kelas A dan Kelas B Semester Tujuh Pada STAIN Palangka Raya .

Desain ini researchused Quasi eksperimental seperti yang dimaksudkan untuk mempelajari tentang kemampuan esai argumentatif mahasiswa. Dalam rangka untuk mengumpulkan data yang diperlukan, peneneliti menggunakan tes sebagai instrumen. Jenis tes dalam penelitian ini adalah Menulis Akademik untuk tes IELTS . Data diolah dan dianalisis dengan menggunakan teknik statistik SPSS 19.0 dari $\mathrm{t}$-test independen dan berpasangan - sample $\mathrm{t}$-test , dan membuat kesimpulan berdasarkan hasil analisis data.

Dari hasil tes . Perhitungan $\mathrm{t}$-test independent dalam skor posttest pada kedua kelompok menunjukkan bahwa nilai signifikansi lebih tinggi dari tingkat signifikansi ( 0.194>0.05) . Hal ini menunjukkan bahwa tidak ada perbedaan yang signifikan antara kelompok eksperimen dan kontrol . Selain itu, perhitungan $t$-test berpasangan menunjukkan hasil uji sampel berpasangan $(0,000<0,05$ ) dimana ada perbedaan yang signifikan antara pretest dan posttest pada kelompok eksperimen setelah perawatan .
\end{abstract}

\section{Kata Kunci : Critical Thinking, Argumentative Essay}

\section{PENDAHULUAN}

Bahasa Inggris merupakan bahasa Internasional. Di Indonesia, bahasa Inggris diajarkan sebagai bahasa asing (English as a Foreign Languange/EFL) mulai dari Sekolah Dasar sampai Perguruan Tinggi (Huda, 1999, dalam Saukah, 2003). Orangorangmenyadari bahwapengajaranbahasa Inggris di tingkatinimenjadi sangat pentingdanmembutuhkan banyakperhatian. Sebagaiseorang guru bahasa Inggris, iadituntutuntuk mengeksplorasiteknik yang efektif, metode dan pendekatan.

Bahasa Inggris diajarkan dalam bentuk "General English" atau "Language Form” (bentuk bahasa), pembentukan kata, ejaan, ucapan, dan sebagainya diintegrasikan ke dalam keempat keterampilan berbahasa, yaitu menyimak, berbicara, membaca dan menulis.Para siswa harus menguasai empat keterampilan bahasa tersebut sehingga mereka dapat menggunakan bahasa Inggris aktif dan pasif juga.Writing (menulis) sebagai bagian dari keterampilan bahasa selain menyimak, berbicara, dan membaca, harus diajarkan secara maksimal oleh guru kepada siswa.

Critical Thinking (Berpikir kritis) telah menjadi bagian penting sebagai keterampilan atau kemampuan karena tiap individu dihadapkan dengan keharusan membuat keputusan penting yang mempengaruhi diri mereka sendiri dan masyarakat pada umumnya (Halpern, 1996, 1998, citied di Renaud dan Murray, 2008: 85). Di Indonesia, berpikir kritis telah

\footnotetext{
* A'am Rifaldi Khunaifi, M.Pd Dosen FKIP Universitas Muhammadiyah Palangkaraya
} 
menjadi kata kunci baru selama sepuluh tahun terakhir, terutama sejak era reformasi. Berpikir kritis telah menjadi salah satu aspek yang telah diasumsikan penting dalam kebijakan pemerintah, terutama di bidang pendidikan (Depdiknas, 2011, Alwasilah, 1998).

Critical thinking (Berpikir kritis) merupakan elemen sangat penting dari semua bidang profesional dan akademik (by referencing their respective sets of permissible questions, evidence sources, criteria, etc.) . Dalam kerangka skeptisisme ilmiah, proses berpikir kritis melibatkan akuisisi yang hati-hati dan interpretasi informasi dan penggunaannya untuk mencapai kesimpulan yang baik dan dibenarkan.Konsep dan prinsip-prinsip berpikir kritis dapat diterapkan untuk setiap konteks atau kasus tetapi hanya dengan merenungkan sifat yang aplikasikan tersebut. Bentuk berpikir kritis, oleh karena itu, sebuah sistem yang terkait, dan overlapping, pemikiran seperti berpikir antropologis, sosiologis berpikir, berpikir sejarah, pemikiran politik, berpikir psikologis, pemikiran filsafat, pemikiran matematis, berpikir kimia, biologi , pemikiran pemikiran ekologis, pemikiran hukum , pemikiran etis, pemikiran musik, berpikir seperti seorang pelukis, pematung, insinyur, orang bisnis, dll Dengan kata lain, meskipun prinsip-prinsip berpikir kritis bersifat universal, aplikasi mereka untuk disiplin membutuhkan proses kontekstualisasi reflektif.

Citical Thinking (Berpikir kritis) dianggap penting dalam bidang akademik karena memungkinkan seseorang untuk menganalisis, mengevaluasi, menjelaskan dan merestrukturisasi pemikiran mereka, sehingga mengurangi resiko mengadopsi, bertindak atas atau berpikir dengan, keyakinan palsu.Namun, bahkan dengan pengetahuan tentang metode penyelidikan logis dan penalaran, kesalahan dapat terjadi karena ketidakmampuan seorang pemikir untuk menerapkan metode atau karena karakter egosentrisme tersebut. Berpikir kritis mencakup identifikasi prasangka, bias, propaganda, penipuan diri, distorsi, kesalahan informasi, dll penelitian Mengingat dalam psikologi kognitif, beberapa pendidik percaya bahwa sekolah harus fokus pada mengajar siswa mereka keterampilan berpikir kritis dan budidaya sifat intelektual. Citical Thinking (Berpikir kritis) dianggap penting dalam bidang akademik karena memungkinkan seseorang untuk menganalisis, mengevaluasi, menjelaskan dan merestrukturisasi pemikiran mereka, sehingga mengurangi resiko mengadopsi, bertindak berdasarkan berpikir dengan, .Namun, bahkan dengan pengetahuan tentang metode penyelidikan logis dan penalaran, kesalahan dapat terjadi karena ketidakmampuan seorang pemikir untuk menerapkan metode atau karena karakter egosentrisme tersebut. Berpikir kritis mencakup identifikasi prasangka, bias, propaganda, penipuan diri, distorsi, kesalahan informasi, dll penelitian Mengingat dalam psikologi kognitif, beberapa pendidik percaya bahwa sekolah harus fokus mengajar siswa mereka dalam keterampilan berpikir kritis dan budidaya sifat intelektual.

Writing (menulis) adalah juga media komunikasi. Menurut Byrne (1980: 24) menulis adalah sarana utama pidato rekaman, meskipun harus diakui sebagai media sekunder komunikasi, sehingga dapat membantu kita untuk memiliki sosialisasi yang baik, dapat mengekspresikan ide kita, perasaan dan pendapat kita sehingga kita dapat memiliki interaksi yang baik dengan masyarakat kita. 
Penulis dapat menyimpulkan bahwa writing (menulis) adalah hal yang sangat penting karena dalam menulis kita harus berbagi ide dari otak kita, tidak mudah untuk menerjemahkan konsep di otak kita untuk menjadi bahasa tertulis dan kita juga harus pandai memilih dan untuk menggabungkan kosakata untuk menciptakan sesuatu yang bermakna. Kita juga harus memperhatikan tata bahasa, sehingga sangat wajar jika siswa berpikir dan menulis adalah pelajaran yang sulit karena mereka harus memperhatikan banyak hal (ide, konsep, kosa kata dan tata bahasa).

\section{RUMUSAN MASALAH}

Permusan masalah dalam penelitian ini di uraikan sebagai berikut:

Apakah Pengajaran Critical Thinking (berpikir kritis) memberikan efek terhadap mahasiswa dalam penulisan argumentatif untuk semester tujuh di STAIN Palangkaraya Tahun Akademik 2013/2014?

\section{METODE PENELITIAN}

Dalam penelitian ini penulis menggunakan kuasi-eksperimental, bagian pertama dari menciptakan desain kuasieksperimental adalah untuk mengidentifikasi variabel. Variabel kuasiindependen akan menjadi x-variabel, variabel yang dimanipulasi dalam rangka untuk mempengaruhi variabel dependen. $\mathrm{X}^{\prime \prime}$ umumnya pengelompokan variabel $\mathrm{q}$ dengan tingkat yang berbeda. Pengelompokan berarti dua atau lebih kelompok seperti kelompok perlakuan dan plasebo atau kelompok kontrol (plasebo lebih sering digunakan dalam percobaan medis atau fisiologis).Hasil prediksi adalah variabel dipendent, yang merupakanyvariabel. Dalam analisis series, variabel dependen yang diamati dari waktu ke waktu untuk setiap perubahan yang mungkin terjadi. Setelah variabel telah diidentifikasi dan didefinisikan, prosedur kemudian harus dilaksanakan dan perbedaan kelompok harus diperiksa.

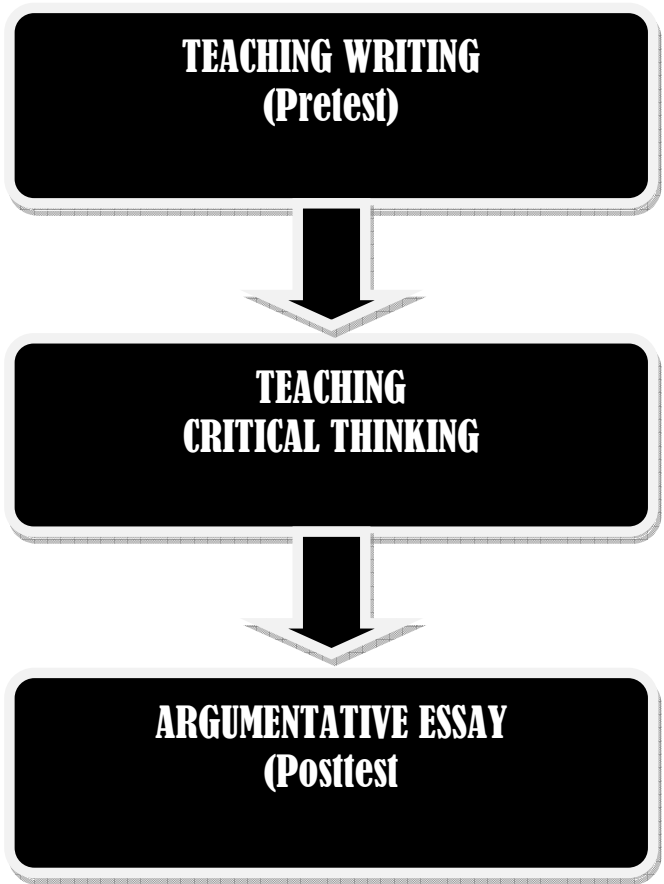


Pedagogik Jurnal Pendidikan, Maret 2014, Volume 9 Nomor 1, (52-63)

\section{PROSEDUR PENELITIAN}

Penelitian ini menggunakan desain eksperimen yang berurusan dengan pengaruh variabel independen, pengaruh mengajar menulis argumentatif untuk berpikir kritis mahasiswa . Desain penelitian yang digunakan adalah desain kuasi - eksperimental yang terkontrol beberapa tapi tidak semua sumber validitas internal ( Tuckman , 1972) . Validitas internal adalah diperluas dimana hasil-hasil penelitian faktor-faktor yang telah dipilih daripada hasil faktor lain yang belum terkontrol ( Tuckman , 1972; HATC \& Farhady, 1982) .
Penelitian ini menggunakan desain kuasi - eksperimental karena desain eksperimental yang benar tidak dapat ditentukan . Sebagai Tuckman (1971) menyatakan bahwa desain penelitian ini ada ketika eksperimental yang benar adalah sulit atau tidak mungkin terjadi . Hal ini karena dunia pendidikan terdiri dari pembatasan yang mempengaruhi peneliti dalam menentukan sampel secara acak . Selain itu variabel dalam penelitian yang berhubungan perilaku manusia sedikit pun , belajar bahasa dan perilaku bahasa yang sulit untuk mengontrol ( Hatch \& Farhady, 1982) . Desain penelitian adalah sebagai berikut

Tabel 1

Quasi-Experimental Design

\begin{tabular}{|c|c|c|c|}
\hline Sample & Pretest & Treatment & Posttest \\
\hline Experimental Group $\left(\mathrm{G}_{1}\right)$ & $\mathrm{T}_{1}$ & $\mathrm{X}$ & $\mathrm{T}_{2}$ \\
\hline Control Group $\left(\mathrm{G}_{2}\right)$ & $\mathrm{T}_{1}$ & - & $\mathrm{T}_{2}$ \\
\hline
\end{tabular}

T1 : Berpikir kritis mahasiswa pada pretest

$\mathrm{X}$ : Treatment

T2 : Berpikir kritis mahasiswa pada posttest

\section{Sampel}

Sampel dari penelitian ini diambil dari mahasiswa kelas Auntuk kelompok kontrol dan kelas B untuk kelompok eksperimen. Dalam rangka untuk mengambil Subjek penelitian peneliti menggunakan metode purposive sampling. Menurut Darrel N. Caulley (1992), purposive sampling digunakan sebagai strategi ketika seseorang ingin memahami sesuatu tentang kasuskasus tertentu tanpa pilih untuk menggeneralisasi untuk semua kasus tersebut. Bahkan mungkin akan dipertanyakan apakah generalisasi mungkin karena sering ada variasi besar di antara kasus, terutama jika kontekstual kasus juga bervariasi.

\section{Validitas Data}

\section{Uji Normalitas Distribusi}

Uji normalitas distribusi dilakukan untuk mengetahui apakah atau tidak data dari kedua kelompok terdistribusi normal . Uji Kolmogrov - Smirnov di SPSS versi 18.0 digunakan dalam menganalisis normalitas distribusi data.

Langkah-langkah menganalisis distribusi normalitas adalah sebagai berikut :

1) Mulai hipotesis Dan menetapkan tingkat alpha 0,05 ( dua sisi) . 
H0 : Sampel kontrol dan eksperimental kelompok terdistribusi secara normal . H1 : Sampel kontrol dan eksperimental kelompok yang tidak terdistribusi normal

2) Menganalisis biasanya distribusi menggunakan Kolmogorov - Smirmov di SPSS vertion 18,0 .

3) Membandingkan Asymp . Sig ( probabilitas) dengan tingkat signifikansi $(0,05)$ untuk menguji hypnothesis tersebut . Jika asymp tersebut .Sig . Apakah lebih dari tingkat signifikansi , maka Hipotesis nol ( $\mathrm{H} 0$ ) dipertahankan . Jika asymp tersebut .Sig . Kurang dari tingkat signifikansi, maka Hipotesis nol (H0) ditolak ( menetas \& farhady , 1982: 88 )

\section{Uji Homogenetity Varians}

Desain penelitian ini adalah Quasi Experimental Desain .Desain melibatkan suatu kelompok dan kelompok kontrol eksperimental. Kedua kelompok diberi pre test dan post-test, Berdasarkan Campbell dan Stanley (1963 : 47 )

\section{Hasil Penelitian}

Data dikumpulkan dari pemberian posttest dan pretest . Pengujian ini dilakukan dalam kelompok kontrol dan kelompok eksperimental , sedangkan test IELTS hanya diberikan kepada kelompok eksperimental .
Hasil tes dihitung dengan rumus statistik dengan bantuan SPSS versi 19.0 untuk mengetahui pengaruh berpikir kritis terhadap esai argumentatif mahasiswa .

Skor pretest dan posttest dianalisis dengan rumus statistik $\mathrm{t}$-test . Itu digunakan untuk mengetahui apakah ada perbedaan yang signifikan antara sarana dua kelompok dalam penelitian ini atau tidak. Berdasarkan perhitungan , untuk mengetahui pengaruh berpikir kritis terhadap esai argumentatif mahasiswa .

\section{Skor Pretest}

Sebelum menghitung nilai $\mathrm{t}$, ada satu asumsi yang harus dipenuhi : sampel berasal dari populasi yang biasanya didistribusikan ( Coolidge , 2000)

\section{Uji distribusiNormalitas}

Langkah pertama dari mulai hipotesis . Hipotesis penelitian ini adalah :

H0: sampel kontrol dan eksperimental kelompok terdistribusi secara normal.

H1: sampel kontrol dan eksperimental kelompok yang tidak terdistribusi normal. Tingkat alpha sebesar 0,05 (tow-tailed), kemudian menganalisis distribusi normalitas menggunakan KollmogrovSmirnov di SPSS 19.0. Jika probabilitas (Sig Asymp.) lebih kecil dari 0,05, maka H0 ditolak. Sementara itu, jika probabilitas lebih besar dari 0,05, maka H0 dipertahankan (Hatch dan Farhady, 1982: 88) 
Pedagogik Jurnal Pendidikan, Maret 2014, Volume 9 Nomor 1, (52-63)

Tabel 2

Uji Distribusi Normalitas di Prestest Kontrol dan Kelompok Experimental One-Sample Kolmogorov-Smirnov Test

\begin{tabular}{|ll|r|r|}
\hline & & \multicolumn{1}{c|}{$\begin{array}{c}\text { Pretest } \\
\text { control }\end{array}$} & \multicolumn{1}{c|}{$\begin{array}{c}\text { Pretest } \\
\text { experimental }\end{array}$} \\
\hline $\mathrm{N}$ & & 26 & 26 \\
Normal Parameters & a,b & 71.3077 & 70.8462 \\
& Std. Deviation & 5.71153 & 6.11027 \\
Most Extreme Differences & Absolute & .241 & .213 \\
& Positive & .129 & .161 \\
& Negative & -.241 & -.213 \\
Kolmogorov-Smirnov Z & & 1.229 & 1.087 \\
Asymp. Sig. (2-tailed) & & .098 & .188 \\
\hline
\end{tabular}

a. Uji distribusi adalah normal

b. Di hitung dari data

Dari tabel di atas, dapat dilihat bahwa nilai probabilitas (Sig Asymp..) Kontrol pretest dan kelompok eksperimen adalah 0.098 dan 0.188. itu berarti bahwa probabilitas melebihi tingkat alpha, dan kemudian HO dipertahankan. Dengan kata lain pretest untuk kontrol dan kelompok eksperimen terdistribusi secara normal.

Hasil tes terdistribusi normal karena nilai dari pretest dari kontrol dan kelompok eksperimen seimbang.

\section{Analisis Skor Posttest}

Serupa dengan analisis data pretest, ada satu asumsi yang harus dipenuhi sebelum menghitung nilai t. Analisis data berikut,

Asumsi yang harus dipenuhi adalah sampel harus terdistribusi normal. Prosedur ini menyatakan hipotesis,

H0: sampel kontrol dan eksperimental kelompok terdistribusi secara normal.

H1: sampel kontrol dan eksperimental kelompok yang tidak terdistribusi normal.

Mengatur tingkat alpha 0,05 (dua sisi). Jika probabilitas (Sig Asymp.) lebih kecil dari 0,05, maka H0 ditolak. Di sisi lain, jika probabilitas lebih besar dari 0,05, maka H0 dipertahankan (Hatch dan Farhady) 
Pedagogik Jurnal Pendidikan, Maret 2014, Volume 9 Nomor 1, (52-63)

Tabel 3

Uji Distribusi Normalitas di Postest Kontrol dan Kelompok Experimental One-Sample Kolmogorov-Smirnov Test

\begin{tabular}{|ll|r|r|}
\hline & & \multicolumn{1}{c|}{$\begin{array}{c}\text { Posttest } \\
\text { control }\end{array}$} & \multicolumn{1}{c|}{$\begin{array}{c}\text { Posttest } \\
\text { experimental }\end{array}$} \\
\hline $\mathrm{N}$ & & 26 & 26 \\
Normal Parameters & aeb & 79.5385 & 80.6154 \\
& Std. Deviation & 2.68672 & 3.18844 \\
Most Extreme Differences & Absolute & .132 & .194 \\
& Positive & .124 & .194 \\
& Negative & -.132 & -.146 \\
Kolmogorov-Smirnov Z & & .673 & .988 \\
Asymp. Sig. (2-tailed) & & .756 & .283 \\
\hline
\end{tabular}

a. Uji distribusi adalah Normal.

b. Di hitung dari.

Menurut tabel tersebut, itu parametrik dilakukan.Rumus t-test menunjukkan bahwa (Asymp.Sig) dari kontrol posttest dan kelompok eksperimen adalah 0,756 dan 0,283. Karena nilai-nilai yang lebih tinggi dari tingkat signifikansi $(0,05)$, ini menunjukkan bahwa sampel terdistribusi normal. Menurut Sudrajat (1983: 388) tingkat signifikansi mampu menurunkan ke 0.020 sebagai level terendah signifikansi dalam statistik. Jika tingkat signifikansi adalah 0,020, maka posttest dari kelompok kontrol terdistribusi normal.

Hasil tes terdistribusi normal karena nilai dari postest dari kontrol dan kelompok eksperimen seimbang

\section{Perhitungan t-test}

Independent t-test Perhitungan Skor Pretest di Kelas Kontrol dan Kelas eksperimen.

Karena sampel penelitian ini independent digunakan untuk menganalisa apakah ada perbedaan yang signifikan antara sarana kedua kelompok atau tidak.

Hipotesis menyatakan sebelum menghitung nilai t adalah:

H0: tidak ada perbedaan yang signifikan antara sarana pretest Kelompok kontrol dan kelompok eksperimen.

H1: ada perbedaan yang signifikan dalam cara pretest antara kontrol dan eksperimen Tingkat signifikansi yang digunakan dalam t-test independent adalah 0,05 (dua sisi). nilai $\mathrm{t}$ dihitung menggunakan rumus t-test independen di SPSS 19.0. Jika nilai signifikansi pretest kontrol dan kelompok eksperimen lebih kecil dari 0,05, maka H0 ditolak. Di sisi lain, jika nilai signifikansi lebih besar dari 0,05, maka $\mathrm{H} 0$ dipertahankan (Hatch dan Farhady, 1982: 88)

terdistribusi secara normal, maka uji

* A'am Rifaldi Khunaifi, M.Pd Dosen FKIP Universitas Muhammadiyah Palangkaraya 
Pedagogik Jurnal Pendidikan, Maret 2014, Volume 9 Nomor 1, (52-63)

Tabel 4

Independent t-test dariskor Pretest kelaskontrol dan Eksperimen

Independent Samples Test

\begin{tabular}{|c|c|c|c|c|c|c|c|c|c|c|}
\hline & \multicolumn{2}{|c|}{$\begin{array}{c}\text { Levene's } \\
\text { Test for } \\
\text { Equality } \\
\text { of } \\
\text { Variance } \\
\text { s } \\
\end{array}$} & \multicolumn{7}{|c|}{ t-test for Equality of Means } \\
\hline & & \multirow[b]{2}{*}{$\mathrm{F}$} & \multirow[b]{2}{*}{ Sig. } & \multirow[b]{2}{*}{$\mathrm{t}$} & \multirow[b]{2}{*}{ df } & \multirow{2}{*}{$\begin{array}{l}\text { Sig. (2- } \\
\text { tailed) }\end{array}$} & \multirow{2}{*}{$\begin{array}{c}\text { Mean } \\
\text { Differen } \\
\text { ce }\end{array}$} & \multirow{2}{*}{$\begin{array}{l}\text { Std. } \\
\text { Error } \\
\text { Differen } \\
\text { ce }\end{array}$} & \multicolumn{2}{|c|}{$\begin{array}{c}95 \% \\
\text { Confidence } \\
\text { Interval of the } \\
\text { Difference }\end{array}$} \\
\hline & & & & & & & & & Lower & Upper \\
\hline pretest & $\begin{array}{l}\text { Equal } \\
\text { variance } \\
\text { s } \\
\text { assume } \\
\text { d }\end{array}$ & $\begin{array}{r}.84 \\
3\end{array}$ & $\begin{array}{r}.36 \\
3\end{array}$ & $\begin{array}{r}.28 \\
1\end{array}$ & 50 & .780 & .46154 & 1.64032 & \begin{tabular}{r|}
- \\
2.8331 \\
4
\end{tabular} & $\begin{array}{r}3.756 \\
22\end{array}$ \\
\hline & $\begin{array}{l}\text { Equal } \\
\text { variance } \\
\text { s not } \\
\text { assume } \\
\text { d }\end{array}$ & & & $\begin{array}{r}.28 \\
1\end{array}$ & $\begin{array}{r}49.77 \\
4\end{array}$ & .780 & .46154 & 1.64032 & $\begin{array}{r}- \\
2.8335 \\
1\end{array}$ & $\begin{array}{r}3.756 \\
59\end{array}$ \\
\hline
\end{tabular}

Dari tabel di atas, ini menunjukkan bahwa nilai signifikansi 0.780 . Sejak 0.780 lebih tinggi dari 0,05, maka H0 dipertahankan yang menyatakan tidak ada perbedaan yang signifikan antara sarana pretest kontrol dan kelompok eksperimen. Ini menyiratkan bahwa kemampuan awal secara tertulis antara kontrol dan eksperimen kelompok adalah serupa.

Hasil skor pretest dalam kontrol dan kelompok eksperimen di atas adalah tidak ada perbedaan yang signifikan karena belum diberi pengobatan.

Independent t-test Perhitungan Skor Postest di Kelas Kontrol dan Kelas eksperimen
Karena sampel penelitian ini terdistribusi secara normal, uji parametrik dilakukan.Independen t-test digunakan untuk menganalisis apakah ada perbedaan yang signifikan antara sarana posttest dari dua kelompok.

Hipotesis dinyatakan sebelum menghitung nilai t:

H0: tidak ada perbedaan yang signifikan antara sarana posttest kontrol dan kelompok eksperimen.

H1: ada perbedaan yang signifikan antara sarana posttest kontrol dan kelompok eksperimen.

Tingkat signifikansi yang digunakan dalam t-test independent adalah 0,05 (dua sisi). Setelah itu, nilai t dihitung menggunakan

* A'am Rifaldi Khunaifi, M.Pd Dosen FKIP Universitas Muhammadiyah Palangkaraya 
Pedagogik Jurnal Pendidikan, Maret 2014, Volume 9 Nomor 1, (52-63)

rumus t-test independent SPSS 19.0. Jika nilai signifikansi posttest kontrol dan eksperimental kelompok yang lebih kecil dari 0,05, maka H0 ditolak. Sementara itu, jika nilai signifikansi lebih besar dari 0,05 , maka H0 dipertahankan (Hatch dan Farhady, 1982: 88).

Analisisnya adalah sebagai berikut :

Tabel 5

\section{Independent t-test dari skor Posttestpada KelompokKontrol danKelompok Eksperimental}

Independent Samples Test

\begin{tabular}{|c|c|c|c|c|c|c|c|c|c|c|}
\hline & \multicolumn{2}{|c|}{$\begin{array}{l}\text { Levene's } \\
\text { Test for } \\
\text { Equality } \\
\quad \text { of } \\
\text { Variances }\end{array}$} & \multicolumn{7}{|c|}{ t-test for Equality of Means } \\
\hline & & \multirow[b]{2}{*}{$\mathrm{F}$} & \multirow[b]{2}{*}{ Sig. } & \multirow[b]{2}{*}{$\mathrm{t}$} & \multirow[b]{2}{*}{$\mathrm{df}$} & \multirow[b]{2}{*}{$\begin{array}{l}\text { Sig. (2- } \\
\text { tailed) }\end{array}$} & \multirow{2}{*}{$\begin{array}{l}\text { Mean } \\
\text { Differen } \\
\text { ce }\end{array}$} & \multirow{2}{*}{$\begin{array}{l}\text { Std. } \\
\text { Error } \\
\text { Differen } \\
\text { ce }\end{array}$} & \multicolumn{2}{|c|}{$\begin{array}{c}95 \% \\
\text { Confidence } \\
\text { Interval of the } \\
\text { Difference } \\
\end{array}$} \\
\hline & & & & & & & & & Lower & $\begin{array}{c}\text { Uppe } \\
\text { r }\end{array}$ \\
\hline Posttest & $\begin{array}{l}\text { Equal } \\
\text { variance } \\
\mathrm{s} \\
\text { assume } \\
\mathrm{d}\end{array}$ & $\begin{array}{r}2.43 \\
5\end{array}$ & $\begin{array}{r}.12 \\
5\end{array}$ & $\begin{array}{r}- \\
1.31 \\
7\end{array}$ & 50 & .194 & 1.07692 & .81770 & $\begin{array}{r}- \\
2.7193 \\
3\end{array}$ & $\begin{array}{r}.5654 \\
8\end{array}$ \\
\hline & $\begin{array}{l}\text { Equal } \\
\text { variance } \\
\text { s not } \\
\text { assume } \\
\text { d }\end{array}$ & & & $\begin{array}{r}1.31 \\
7\end{array}$ & $\begin{array}{r}48.60 \\
3\end{array}$ & 194 & 1.07692 & 81770 & $\begin{array}{r}- \\
2.7205 \\
0\end{array}$ & $\begin{array}{r}.5666 \\
5\end{array}$ \\
\hline
\end{tabular}

Dari tabel di atas menunjukkan bahwa nilai signifikansi sarana posttest kontrol dan kelompok eksperimen adalah 0.194. Hal ini menunjukkan bahwa 0.194is lebih tinggi dari 0,05 , maka H0 dipertahankan yang menyatakan tidak ada perbedaan yang signifikan antara sarana pretest kontrol dan kelompok eksperimen.

Hasil skor postes dalam kontrol dan kelompok eksperimen di atas adalah tidak ada perbedaan yang signifikan setelah diberikan pengobatan.Hal ini terjadi karena nilai hasil postes siswa dalam kontrol dan kelompok eksperimen seimbang. Nilai ratarata kontrol postets eksperimental 80 dan 70

Uji-t berpasangan Perhitungan Skor pretest dan posttest Skor di Kelompok Kontrol.

Sebuah t-test berpasangan dilakukan untuk mengetahui apakah ada perbedaan yang signifikan antara pretest dan posttest 
Pedagogik Jurnal Pendidikan, Maret 2014, Volume 9 Nomor 1, (52-63)

berarti dari kelompok kontrol.Dipasangkan rumus t-tes di SPSS 19.0 digunakan untuk menganalisis skor. Langkah-langkah menganalisis paired t-test serupa dengan analisis t-test independent. Pertama-tama menyatakan hipotesis, yaitu:

Tabel 6

Analisis Skor Pretest and Posttest Scores Pada KelompokKontrol Paired Samples Statistics

\begin{tabular}{|ll|l|r|r|r|}
\hline & & & & \multicolumn{1}{c|}{$\begin{array}{c}\text { Std. Error } \\
\text { Mean }\end{array}$} \\
\hline Pair 1 & Pretest control & 71.3077 & $\mathrm{~N}$ & Std. Deviation & \multicolumn{1}{c|}{$\begin{array}{c}\text { Mean } \\
\end{array}$} \\
& Posttest control & 79.5385 & 26 & 5.71153 & 1.12012 \\
\hline
\end{tabular}

Tabel 7

Skor Paired t-test of Pretest and Posttest Pada KelompokKontrol Paired Samples Test

\begin{tabular}{|c|c|c|c|c|c|c|c|c|c|}
\hline & \multicolumn{5}{|c|}{ Paired Differences } & \multirow[b]{3}{*}{$\mathrm{t}$} & \multirow[b]{3}{*}{ df } & \multirow{3}{*}{$\begin{array}{l}\text { Sig. (2- } \\
\text { tailed) }\end{array}$} \\
\hline & & \multirow[b]{2}{*}{ Mean } & \multirow{2}{*}{$\begin{array}{c}\text { Std. } \\
\text { Deviati } \\
\text { on }\end{array}$} & \multirow{2}{*}{$\begin{array}{l}\text { Std. } \\
\text { Error } \\
\text { Mean }\end{array}$} & \multicolumn{2}{|c|}{$\begin{array}{c}95 \% \\
\text { Confidence } \\
\text { Interval of the } \\
\text { Difference }\end{array}$} & & & \\
\hline & & & & & Lower & Upper & & & \\
\hline Pair 1 & $\begin{array}{l}\text { Pretest } \\
\text { control } \\
\text { - } \\
\text { posttes } \\
\text { t } \\
\text { control }\end{array}$ & $\begin{array}{r}- \\
8.2307 \\
7\end{array}$ & $\begin{array}{r}4.7270 \\
1\end{array}$ & .92704 & $\begin{array}{r}- \\
10.140 \\
05\end{array}$ & $\begin{array}{r}- \\
6.3214 \\
9\end{array}$ & $\begin{array}{r}- \\
8.87 \\
9\end{array}$ & 25 & .000 \\
\hline
\end{tabular}

Tabel 6 menunjukkan bahwa rata-rata skor posttest pada kelompok kontrol lebih tinggi dari skor pretest ( 79,5385> 71,3077 ). Tabel 7 menunjukkan nilai signifikansi adalah 0,000 , yang lebih rendah dari tingkat signifikansi ( 0,05). Akibatnya, H0 ditolak .Ini tersirat bahwa ada perbedaan yang signifikan antara pretest dan posttest sarana kelompok control.

Uji-t berpasangan Perhitungan Skor pretest dan posttest Skor di Kelompok Eksperimen.
Sebuah $t$-test berpasangan juga dilakukan untuk mengetahui apakah ada perbedaan yang signifikan antara sarana kelompok eksperimen sebelum dan setelah perawatan. Dipasangkan rumus $\mathrm{t}$ - tes di SPSS 19.0 digunakan untuk menganalisis pretest dan posttest skor kelompok eksperimen . Langkah-langkah menganalisis paired $\mathrm{t}$-test yang mirip dengan analisis $\mathrm{t}$-test yang dipasangkan pada kelompok kontrol . Pertama menyatakan hipotesis, yaitu:

\footnotetext{
* A'am Rifaldi Khunaifi, M.Pd Dosen FKIP Universitas Muhammadiyah Palangkaraya
} 
HO : tidak ada perbedaan yang signifikan antara pretest dan posttest berarti dari kelompok eksperimen .

H1 : ada perbedaan yang signifikan antara pretest dan posttest berarti dari kelompok eksperimen .

Kemudian , yang menyatakan tingkat signifikansi t 0,05 (dua sisi) . Bandingkan nilai tingkat signifikansi dan nilai signifikansi setelah analisis . Jika nilai signifikansi sama atau lebih rendah dari 0,05 , hasilnya adalah signifikan secara statistik . Maka H0 ditolak, sementara itu, jika nilai signifikansi lebih tinggi dari 0,05, hasilnya tidak signifikan secara statistik, maka H0 dipertahankan ( Hatch dan Farhady ， 1982: $88 \quad$ ) .

\section{Hasil Perhitungannya adalah sebagai berikut :}

Tabel 8

Pretest and Posttest Scores analysis in Experimental Group Paired Samples Statistics

\begin{tabular}{|ll|l|r|r|c|}
\hline & & Mean & $\mathrm{N}$ & Std. Deviation & $\begin{array}{c}\text { Std. Error } \\
\text { Mean }\end{array}$ \\
\hline Pair 1 & Pretest experimental & 70.8462 & 26 & 6.11027 & 1.19832 \\
& Posttest experimental & 80.6154 & 26 & 3.18844 & .62530 \\
\hline
\end{tabular}

Tabel 9

Pretest and Posttest Scores analysis in Experimental Group.

Paired Samples Test

\begin{tabular}{|c|c|c|c|c|c|c|c|c|c|}
\hline & \multicolumn{5}{|c|}{ Paired Differences } & \multirow[b]{3}{*}{$\mathrm{t}$} & \multirow[b]{3}{*}{ df } & \multirow{3}{*}{$\begin{array}{l}\text { Sig. (2- } \\
\text { tailed) }\end{array}$} \\
\hline & & \multirow[b]{2}{*}{ Mean } & \multirow{2}{*}{$\begin{array}{c}\text { Std. } \\
\text { Deviati } \\
\text { on }\end{array}$} & \multirow{2}{*}{$\begin{array}{l}\text { Std. } \\
\text { Error } \\
\text { Mean }\end{array}$} & \multicolumn{2}{|c|}{$\begin{array}{c}95 \% \\
\text { Confidence } \\
\text { Interval of the } \\
\text { Difference } \\
\end{array}$} & & & \\
\hline & & & & & Lower & Upper & & & \\
\hline Pair 1 & $\begin{array}{l}\text { Pretest } \\
\text { experimen } \\
\text { tal - } \\
\text { posttest } \\
\text { experimen } \\
\text { tal }\end{array}$ & $\begin{array}{r}9.7692 \\
3\end{array}$ & $\begin{array}{r}4.5016 \\
2\end{array}$ & .88284 & $\begin{array}{r}11.587 \\
48\end{array}$ & $\begin{array}{r}7.9509 \\
9\end{array}$ & $\begin{array}{r}11.06 \\
6\end{array}$ & $\begin{array}{l}2 \\
5\end{array}$ & .000 \\
\hline
\end{tabular}

Perhitungan ini menunjukkan bahwa ada

kritis pengajaran meningkatkan perbedaan yang signifikan antara pretest dan posttest berarti dari kelompok keterampilan siswa dalam esai eksperimen. Dengan kata lain, pemikiran argumentatif. 
Pedagogik Jurnal Pendidikan, Maret 2014, Volume 9 Nomor 1, (52-63)

\section{DAFTAR PUSTAKA}

Bailin,S Case, R.,Coombs, J and Daniels, L 1990a, Common Misconceptions of Critical Thinking; Journal of Curriculum Studies,31 (3) 269-283

Anderson, M \& Anderson, K. 1997.Text Types in English. South Melbourne: Macmillan Education Australia.

Byrne, Donn.1980. Teaching Writing Skill. London; Longman Group Ltd

Blanchard, K. L \& Root, C. B. 1984.Ready to Write: First Composition Text. New York: Longman

Brown, H. D. 2004. Language Assessments, Principles and Classroom Practices. New York: Longman.

Colton, D. \& Covert, R. W. 2007.Designing and Constructing Instruments for Social Research and Evaluation.Jossey-Bass [e-book]. Available at http://ifile.it/h2co6km/0787987840.zip [september 2011]

Derewianka, B. 2004.Exploring How Text Work. Sydney: Primary English Teaching Association.

Harmer, J. B. 2004.How To Teach Writing.London: Longman

Sugioyono, 2010.Metode Penelitian Pendidikan : Pendekatan Kuantitatif, Kualitatif dan $R \& D$. Alfabeta: Bandung 